\title{
UNA OPCIÓN PARA MEJORAR LA ADAPTACIÓN DE LA ENSEÑANZA DE LAS CIENCIAS A LA COMPRENSIÓN DEL ALUMNADO
}

\author{
ROLdÁN, V. ${ }^{1} \&$ CADOCHE, L. ${ }^{1}$
}

\begin{abstract}
RESUMEN
A través de esta investigación se ha tratado de interpretar la naturaleza de algunas concepciones de los alumnos sobre el proceso de disolución como disparador para el diseño de una propuesta didáctica que teniendo en cuenta estas apreciaciones permita el logro de mayores aprendizajes. Por ello, hemos decidido explorar las ideas de los alumnos del primer año de la carrera de Ciencias Veterinarias de la Universidad Nacional del Litoral sobre aspectos básicos de la Química, como son las disoluciones en una etapa previa a la instrucción sobre el tema. La indagación sobre el tema se realizó a través de dos tipos de preguntas: en una de ellas no se empleaban sustancias concretas para favorecer la composición libre por parte del alumno y la otra propuesta involucró la realización de un dibujo de una disolución de una sustancia, el $\mathrm{NaCl}$, completamente disuelta en agua. A través del análisis de las respuestas a la pregunta que favorece la libre expresión se concluye que el proceso de disolver una sustancia en otra, es visto por el alumno como un fenómeno complejo. Del análisis de los gráficos sobre el proceso de disolución se puede concluir que un $95 \%$ de los alumnos que contestaron la pregunta, aceptan una idea de homogeneidad de la solución. Más de la mitad de los estudiantes reflejan una visión continua de la sustancia disuelta, el soluto.
\end{abstract}

Palabras clave: ideas, disoluciones, sustancias, soluto.

\section{SUMMARY}

\section{Option for to improve the adaptation of the science's education to unders- tanding for student body.}

Through this research it has been tryed to interpret about nature of student's ideas on the dissolution process as shot for drawing of didactic proposal to bear in mind that appreciations permit to achieve of best apprenticeship. For it, we have decided to explore the student's ideas of the first year of the career of Veterinary Sciences of the University of Litoral on basics aspects of the Chemistry, as they are the dissolutions, do it in a previous stage to the instruction on the topic. The investigation on the topic was carried out through two types of questions: in one of them concrete substances were not used, to favor the free composition on the part of student and the other proposal involved the

\footnotetext{
1.- Cátedra de Bioquímica. Facultad de Ciencias Veterinarias, Universidad Nacional del Litoral.

Kreder 2805. (3080) Esperanza, provincia de Santa Fe. Argentina.

E-mail: vroldan@fcv.unl.edu.ar

Manuscrito recibido el 18 de mayo de 2001 y aceptado para su publicación el 5 de marzo de 2002.
} 
realization of a drawing of the dissolution of a substance, $\mathrm{NaCl}$, totally dissolved in water. Through the analysis of the answers to the question that favors the free expression you concludes that the process of dissolving a substance in other, it is seen by the student like a complex phenomenon. Of the analysis of the graphics on the dissolution process you can conclude that $95 \%$ of the students that answered the question, accepts an idea of homogeneity of the solution. But of half of the students they reflect a continuous vision of the dissolved substance, soluto.

Key words: ideas, dissolutions, substances, soluto. 